\title{
An integrated approach to evaluate potential impact of precipitation and land-use change on streamflow in Srepok River Basin
}

\author{
Akiyuki KAWASAKI ${ }^{*}$, Masatsugu TAKAMATSU**, Janet $\mathrm{HE}^{* * *}$, \\ Peter ROGERS ${ }^{\star \star \star \star}$, and Srikantha HERATH ${ }^{\star \star \star \star \star}$
}

\begin{abstract}
To manage water resources effectively at a local level, decision makers need to understand how climate change and human activity may impact local streamflow as a precious natural source of water use. However, the impact is often not well studied with locally obtained data such as monitored flow. This paper presents an integrated approach to study potential impact of precipitation and land-cover change on local streamflow over the next decades. The study area is the Srepok River basin, a tributary sub-basin of the Mekong River. A hydrological model was developed in the Hydrologic Modeling System (HEC-HMS) environment and calibrated using local precipitation and streamflow data. Several scenarios were developed considering climate change and socio-economic development in a GIS environment, and streamflow in 2025 and 2050 was estimated for each scenario. The paper ends with discussion on possible adaptations for a given area.
\end{abstract}

Keywords: river basins, water resources, precipitation, land-use, climate change

\section{Introduction}

In the $21^{\text {st }}$ century, water is at the heart of serious environmental, political and economic issues around the globe. The impact of climate change and population growth on the quantity, variability, and spatial distribution of water resources is increasingly cited as a possible hindrance to economic and social development in many countries around the world.

Climate change and human development are considered major driving forces that will affect future water resources (Kundzewicz et al., 2007; Rogers, 2008). Their contributions to the future state of global water resources have been intensively studied (Milly et al., 2005; Oki and Kanae, 2006; Vorosmarty et al., 2000). To study adaptation to water resource changes, however, attention to local scale is essential because the structure of the solution is different for each scale and set of local characteristics. Concrete adaptations based on practical analysis are often not well studied, particularly on local and regional scales (Pielke, 2005).
To make suitable adaptation plans for water resource use at a local level, decision makers need to understand the extent of the potential impact of both climate change and human activity on local water flow. It is important to compare these factors based on local data to respond to impending climate change and expanding human activity, particularly in fast-growing developing countries.

Geographic Information System (GIS) is a promising tool for integrated river-basin analysis and management. GIS allows rapid arrangement of a geospatial data infrastructure and comprehensive analyses of various other kinds of data at a local level (Downs and Priestnall, 1999; Jarvie et al., 2002; Maidment, 2008). GIS allows us to delineate the watershed boundary from the topography and extract detailed watershed characteristics by overlaying data layers such as population, land-use and climate.

This paper presents an integrated approach to study the potential impact of 'precipitation' and 'land-cover' change on local streamflow over the next decades. The

\footnotetext{
* Member of GISA, Institute of Industrial Science, The University of Tokyo

4-6-1 Komaba, Meguro-ku, Tokyo 153-8505, Japan. E-mail: akiyuki@iis.u-tokyo.ac.jp

** HydroQual, Inc., Mahwah, USA

*** Harvard College, Cambridge, USA

**** School of Engineering and Applied Sciences, Harvard University, Cambridge, USA

$* * * * * \quad$ United Nations University Institute for Sustainability and Peace, Tokyo, Japan
} 
magnitude of the change is demonstrated with different, but likely scenarios. Arc Hydro, a geospatial and temporal data model specifically developed for water resources (Kawasaki et al., 2007; Maidment, 2002; Patino-Gomez et al., 2007; Whiteaker et al., 2006), was used to develop a hydrologic model to simulate streamflow. The model was developed in the Hydrologic Modeling System (HEC-HMS) environment and calibrated using local precipitation and streamflow data. Several scenarios were developed considering climate change and socio-economic development in a GIS environment, and streamflow in 2025 and 2050 was estimated for each scenario.

\section{Study Area}

The Mekong River is the longest international river in Asia, rising in the Tibetan Plateau and emptying into the South China Sea. It travels $4,000 \mathrm{~km}$ and flows through six countries: China, Myanmar, Thailand, Lao PDR, Cambodia, and Vietnam. As the World Wildlife Fund (2008) reported, over a thousand new species have been discovered in the Greater Mekong Basin in just the last decade; indeed, it is one of the richest remaining biodiversity areas in the world and many inhabitants rely on it for their livelihood.

Hydrology and water resources in the Mekong have been thoroughly studied to simulate unique phenomena of the Asian Monsoon Region (Takeuchi, 2008). General Circulation Models (GCMs) or self-produced distributed hydrological model were used to investigate hydrology and water balance at the entire basin level (Ishidaira et

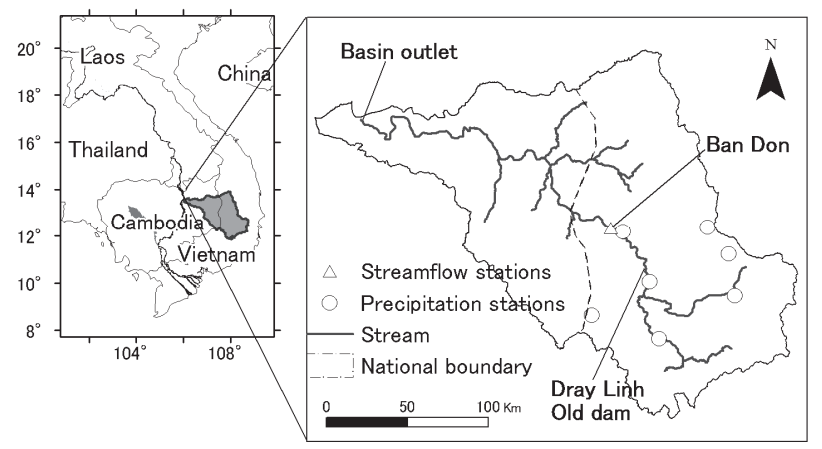

Fig. 1 Research site and the hydro-meteorological stations al., 2008; Kiem et al., 2008; Haddeland et al., 2006). GIS has been used for analyzing local-scale flood risk and climate change impact on agriculture, but many research works mainly focus on Thailand (Weesakul, 2010; Rajin and Shibasaki, 2000) or the Mekong Delta in Vietnam (Wassmann et al., 2004; Boochabun et. al.; 2007; Haruyama and Hoa, 2010), so there is a geographic imbalance in the knowledge distribution.

The Srepok River basin, a sub-basin in the Lower Mekong which straddles the two national borders of Cambodia and Vietnam, was selected as a study area (Fig. 1). Scientific investigation on future available water is required in this sub-basin to study water resource adaptation because rapid population growth, agricultural development, and several dam projects planned upstream in Vietnam may threaten the valuable ecosystem and the economic survival of downstream residents in Cambodia (Mekong River Commission, 2007). The Cambodian side remains largely covered in thick forests, whereas the Vietnamese side features a small, concentrated urban population of 390,660 as of 2004 in Buon Ma Thuot, which has a total area of less than $10 \mathrm{~km}^{2}$ (CarlBro Intelligent Solutions, 2005). There is also significant agricultural development, a hydropower dam (Dray Linh Old), and reservoir systems that control flow and collect hydrological data. The climate in the area is very humid (78$83 \%$ annual humidity) and features a distinct wet and dry season. The wet season lasts from May to October (with peak floods often in September or October) and accounts for over $75-95 \%$ of the region's annual precipitation.

\section{Method}

\section{1 Overview}

The overall structure of this research involves the integration of two software programs - a hydrological simulation tool, Hydrologic Modeling System (HECHMS) (US Army Corps of Engineers, 2009) and a GIS environment (ArcGIS) through the use of two ArcGISbased system applications: Arc Hydro Tools (Maidment, 2002) and the Geospatial Hydrologic Modeling Exten- 
sion (HEC-GeoHMS). This enabled us to effectively process local geospatial and climate data into one integrated model of the hydrological processes. This provides a holistic and coherent database, supporting a series of processes including data generation, management, analysis and simulation, problem-solving, and demonstration, that are required commonly in water resources and riverwatershed management. Another advantage of combining these tools is that one can reflect effects of changes in climate and land-cover over time on a local scale, which is very helpful for scenario analysis.

Then, streamflow in 2025 and 2050 was estimated by considering the potential impact of climate change and socio-economic development on water supply and demand from domestic and agricultural uses. Scenarios of 'Precipitation change only', 'Land-cover change only' and 'Both precipitation and land-cover change' were considered in the model to evaluate future flow conditions.

\section{2 Hydrologic Model Development}

ArcGIS was used to develop a dataset to build a hydrologic model. Terrain processing tools in the Arc Hydro tools application were used to delineate sub-watersheds from a 50m DEM (Digital Elevation Model) of the Srepok River basin. Time-series precipitation data was mapped from seven precipitation observation sites (Ban Don, Duc Xuyen, Cau 14, Krong Buk, Buon Ho, Dak Mil, Krong Bong) in Vietnam using Thiessen's Polygon method (Longley et al., 2005), and allocated to individual subbasins based on their aerial proportions. No rain data was readily available for the Cambodian side; all sub-basins in Cambodia are assumed to have uniform precipitation estimated from data from the Vietnamese side.

The land surface characteristics used in this study were based on the U.S. Soil Conservation Service (SCS) curve number (CN) system (McCuen, 1982; Soil Conservation Service, 1986), which determines a runoff coefficient from a simple land-use and soil drainage type table. With available land-cover and soil type maps for the region and a modified $\mathrm{CN}$ lookup table to match key land-use types of interest in this study, curve numbers and curve number based lag times were estimated for each individual sub-basin. These calculations were all executed in the ArcGIS environment using the HEC Geo-HMS Tools application.

Land-cover data compiled by the Mekong River Commission (MRC) in 1997 consisted of 21 categories which were integrated into six categories shown at Table 1. For example, "Thick cover forest" consists of high cover density of evergreen or mixed forest (evergreen and deciduous). "Thin cover forest" consists of medium - low cover density of evergreen or mixed forest (evergreen and deciduous), or regrowth forest. "Agriculture" consists of agricultural land, plantations, or cropping mosaic based on the MRC's classification. SCS curve numbers were generated from a modified curve number lookup table (Table 1) and averaged over the entirety of the sub-basin.

The Muskingum Routing method was selected to model stream routing. Assumptions include a Muskingum $X$ value of 0.1 (indicating a small, natural stream), a subreach value of 2 , and a streamflow speed of $3.2 \mathrm{~km} / \mathrm{hr}$ was used to calculate Muskingum $K$ value (length of time to travel a stream reach).

Table 1 Curve number table for Antecedent Moisture Conditions II (regular conditions)

\begin{tabular}{l|c|c|c|c}
\hline \multirow{2}{*}{} & \multicolumn{4}{|c}{ Soil Type } \\
\cline { 2 - 5 } & $\mathrm{A}$ & $\mathrm{B}$ & $\mathrm{C}$ & $\mathrm{D}$ \\
\hline \hline Thick cover forest & 30 & 55 & 70 & 77 \\
\hline Thin cover forest & 43 & 65 & 76 & 82 \\
\hline Mosaic & 43 & 65 & 76 & 82 \\
\hline Glass land & 30 & 58 & 71 & 78 \\
\hline Agriculture & 67 & 77 & 83 & 87 \\
\hline Urban & 89 & 92 & 94 & 95 \\
\hline
\end{tabular}

* Soil Type ranges from A (absorbent) to D (not absorbent). This table is base on MaCuen (1982) and Soil Conservation Service (1986).

3. 3 External Calculation Process in Precipitation Abstraction

In this study, it was critical to represent hydrological 
process with a SCS curve number so that future landcover change could be represented by curve number change. However, the SCS method for abstraction (interception, depression storage, and infiltration) is more suitable for event simulation than continuous simulation because initial abstraction should be fully updated at the beginning of each storm event, which is not easy in the SCS module in HEC-HMS. In order to conduct continuous simulation in the HEC-HMS environment, excess precipitation was externally calculated with the SCS abstraction method and directly brought into the model.

In the SCS method, abstraction, $F a$, is represented as:

$$
F_{a}=\frac{S\left(P-I_{a}\right)}{P-I_{a}+S}
$$

where $S$ is potential maximum retention, $P$ is precipitation, and $I_{a}$ is initial abstraction. The potential maximum retention, $S$, for normal antecedent moisture conditions is empirically defined as follows with given curve number, $C N$ :

$$
S=\frac{1000}{C N}-10
$$

The retention $S$ can be further adjusted based on 5-day antecedent precipitation (Chow et al., 1988). Initial abstraction, $I_{a}$, was also defined as $0.2 \mathrm{~S}$ as suggested.

In this study, 17 precipitation events in 2001, which have depth greater than $30 \mathrm{~mm}$ in all the 7 precipitation stations in the basin, were selected using daily precipitation data. Each storm event was split into two when there is a period with rainfall less than $3 \mathrm{~mm}$ within 72 hours. For each precipitation event, $C N, S$, and $I_{a}$, were calculated based on the 5-day antecedent precipitation. Figure 2 shows actual daily hyetograph and calculated excess precipitation for the 11 th precipitation event in 2001, the largest precipitation event during the year. The graph shows the excess precipitation for $C N$ of 70 and 80 . Excess precipitation is greater for $C N=80$ than $C N=70$ especially during initial and peak period of the storm. This is because initial abstraction, $I_{a}$, and potential maximum retention, $S$, are both smaller for larger $C N$ value (i.e., urbanized case). In this example, calculated amount of excess precipitation with $C N=70$ is $307 \mathrm{~mm}$ and $C N=80$ is $380 \mathrm{~mm}$ among the total $487 \mathrm{~mm}$ precipitation.

For a given $C N$ value, excess precipitation was calculated for each event with the external process, and then combined as a continuous time-series data to conduct a continuous simulation in HEC-HMS.

\section{4 Model Calibration}

This pre-processed data was then integrated into the HEC-HMS environment. Calibration was conducted using observed daily streamflow at Ban Don in 2001. Simulation results were compared to the observed streamflow at the Ban Don station in 2001 (Fig. 3). In the calibration process, the lag time and Muskingam $K$ values were mainly used as calibration parameters whereas the estimated $C N$ based on land-use data were kept as estimated. In the study sub-basin, an existing hydropower dam called Dray Linh Old has been in operation in Dak Lak Province, approximately $30 \mathrm{~km}$ upstream of the Ban Don streamflow observation point (Fig. 1). The dam has an active storage of $1.5 \mathrm{Mm}^{3}$ and a water depth difference between design head and minimum head of $4 \mathrm{~m}$. To generate electricity, a discharge of $90 \mathrm{~m}^{3} / \mathrm{s}$ is designed to be diverted to the turbine structure (SWECO Groner, 2006). The dam with the active storage can be emptied in less than 5 hrs with the design discharge without inflow. With a $500 \mathrm{~m}^{3} / \mathrm{s}$ of wet weather flow, the dam can be filled from the minimum depth for about an hour. The dam may moderate a flood peak slightly only until the dam fills, however the influence is minimal because of the small storage volume of the dam. Therefore, this hydropower dam was not considered as storage in the simulation.

In addition, there are 484 small reservoirs and 76 diversion dams on the Vietnamese side of the border with an approximate volume of $280 \mathrm{Mm}^{3}$ as of 2006 (Ty et al., 2009). This volume is approximately $15 \%$ for the total precipitation volume in the area. Their capacity and local water use pattern in paddy field can impact on basin-wide hydrological process including $C N$ value representation 


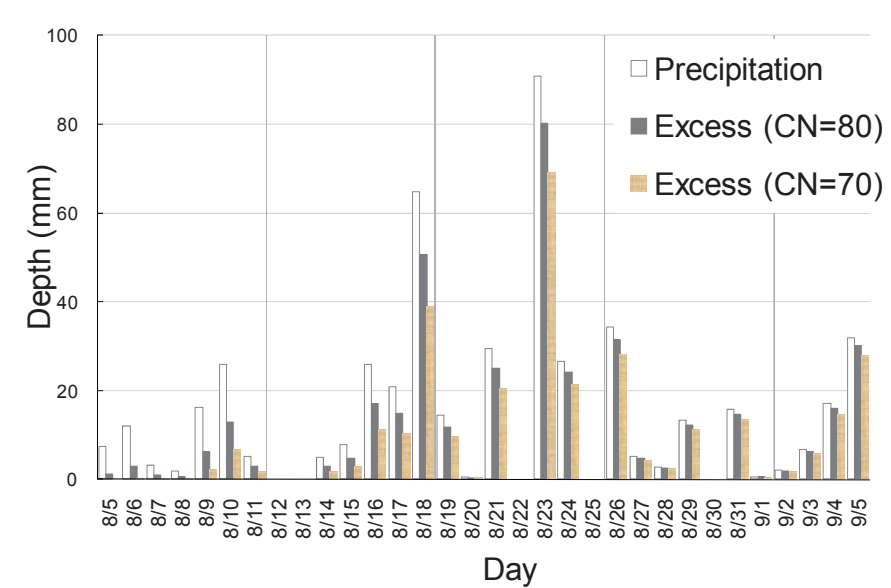

Fig. 2 Storm hyetograph for August $5^{\text {th }}, 2001$ and calculated excess precipitation for $C N=70$ and 80

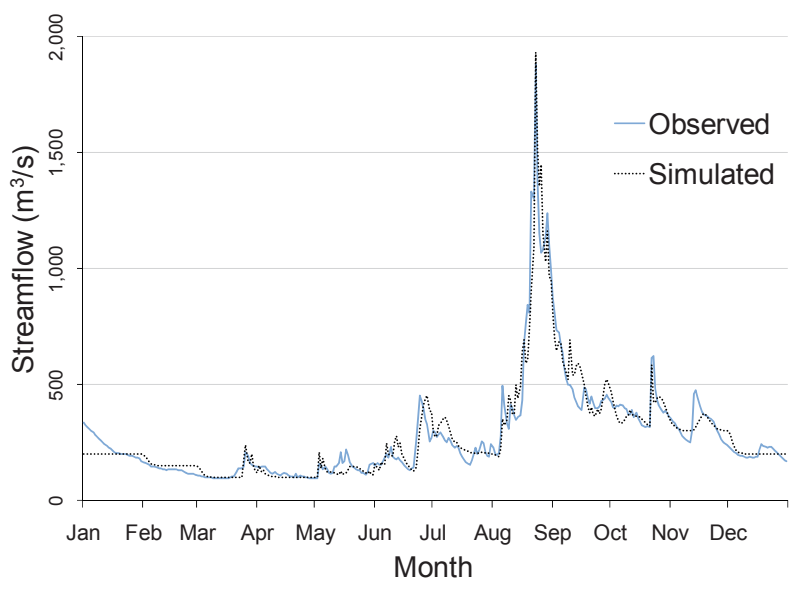

Fig. 3 Observed and simulated streamflow at Ban Don observation station in 2001
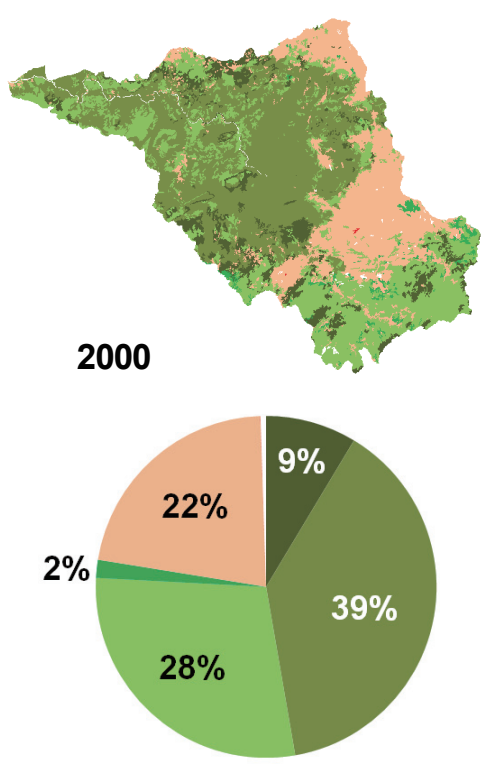

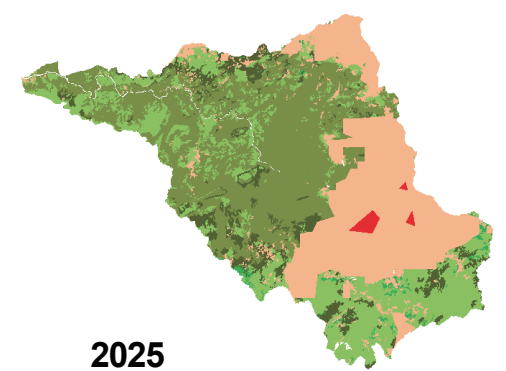

2025

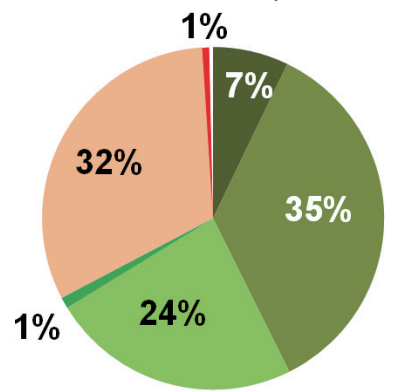

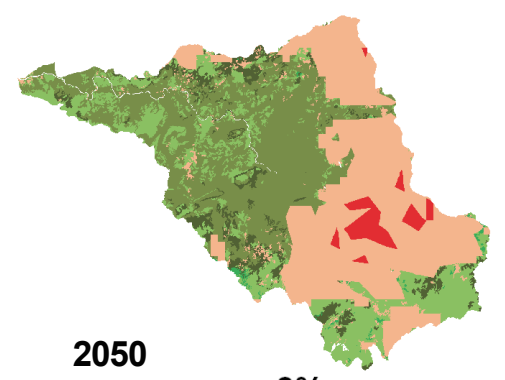

$3 \%$

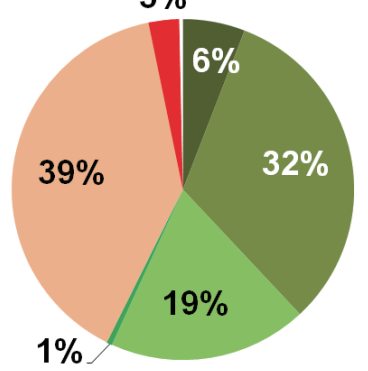

- Thick forest $\quad$ Thin forest $\quad$ Mosaic $\quad$ Grassland $\quad$ Agriculture $\quad$ Urban $\square$ Other

Fig. 4 Existing land-cover in 2000, and predicted land-cover in 2025 and 2050

of paddy field. However in this research, due to the lack of spatial and volumetric information of each small dam and reservoir, model development and calibration process in agricultural water use had to be simplified. Instead of adjusting $C N$ values for agricultural area or explicitly include reservoirs in the model, we used depression storages and runoff routing coefficients to reproduce overall hydrologic process in the Srepok River basin. This storage data is being collected and will be utilized in future studies.

\section{5 Creating Future Land-Cover Scenarios}

Land-cover data was used to determine two key factors in the future streamflow estimation: runoff and water demand. Future land-cover scenarios were developed to evaluate the impact of future land development. Though many land-use models have been developed using GIS (Almeida et al., 2008; Nagasaki et al., 2006: Steinitz et al., 2005; Xia and Xiaoping, 2008), a simple approach was taken for scenario analysis of this study due to the limited data access. To reflect urban and agricultural development in 2025 and 2050, existing population density 
data was used to model future land-use policy decisions. A local annual population growth rate of $1.95 \%$ (CarlBro Intelligent Solutions, 2005) for the upper side of the Srepok River basin was uniformly applied across population density grids from 2000 (CIESIN, 2008) to generate population density grids for 2025 and 2050, though the actual relationship between population growth and land use conversion is complex and changing depending on the transition stage of the region (Acharya and Nangia, 2004).

To develop land-cover and population density relationship in the sub-basin, population density grids for 2000 were cross-related with the land-cover polygon of 1997. From the cross comparison, the population density ranges in Table 2 were proposed for each land-cover in this study area. Approximately $73 \%$ of the agricultural area and $75 \%$ of the urban area in the observed landcover polygon for 1997 fall into their respective proposed population density ranges, which supports the validity of these proposed ranges. The proposed ranges were then applied to the new population density grids for 2025 and 2050 to predict future land-cover with the assumption that land-cover change is highly dependent on population growth. Existing undeveloped land (i.e. forest) could become more developed as population increases, but not vice versa. Like so, land-cover polygons for 2025 and 2050 were generated (Fig. 4). As shown in the figure, the Vietnam side of the basin is much more developed for agricultural use than the Cambodian side. The parameters of the runoff process of each sub-basin $(C N$, lag times, and Muskingum $K$ ) were recalculated based on these two new land-cover scenarios for their respective future simulations.

Land-cover change, specifically urban and agricultural development, significantly affects human water demand. Annual water demand in the Vietnam side of upper Srepok River basin in 2004 was $1,618 \mathrm{Mm}^{3}$ for agriculture and $51.8 \mathrm{Mm}^{3}$ for urban area, where $30.5 \mathrm{Mm}^{3}$ for industry and $21.3 \mathrm{Mm}^{3}$ for domestic uses (CarlBro Intelligent Solutions, 2005). These total water demand values and
Table 2 Population density ranges for each land-cover in the study area

\begin{tabular}{c|c}
\hline Land-cover category & $\begin{array}{c}\text { Population density range } \\
\left(\text { persons } / \mathrm{km}^{2} \text { ) }\right.\end{array}$ \\
\hline \hline Thick cover forest & $0-7$ \\
\hline Thin cover forest & $8-15$ \\
\hline Mosaic & $16-23$ \\
\hline Open land & $24-31$ \\
\hline Grassland & $32-47$ \\
\hline Agriculture & $48-799$ \\
\hline Urban & over 800 \\
\hline
\end{tabular}

Table 3 Agricultural and urban water demand per unit area in the Vietnamese side of upper Srepok River basin

\begin{tabular}{c|c|c|c}
\hline & $\begin{array}{c}\text { Water } \\
\text { demand } \\
\left(\mathrm{Mm}^{3}\right)\end{array}$ & $\begin{array}{c}\text { Area } \\
\left(\mathrm{km}^{2}\right)\end{array}$ & $\begin{array}{c}\text { Water demand } \\
\text { per area } \\
\left(\mathrm{Mm}^{3} / \mathrm{km}^{2}\right)\end{array}$ \\
\hline \hline Agriculture & $1,618.0$ & $5,996.6$ & 0.27 \\
\hline Urban & 51.8 & 6.7 & 7.73 \\
\hline
\end{tabular}

Table 4 Projected increase of total water demand from 2000 at Ban Don and basin outlet in 2025 and 2050

\begin{tabular}{c|c|c|c}
\hline \multicolumn{2}{c|}{} & $\begin{array}{c}\text { Dry season } \\
\left(\mathrm{m}^{3} / \mathrm{s}\right)\end{array}$ & $\begin{array}{c}\text { Wet season } \\
\left(\mathrm{m}^{3} / \mathrm{s}\right)\end{array}$ \\
\hline \hline \multirow{3}{*}{ Ban Don } & 2025 & 81.5 & 40.8 \\
\cline { 2 - 4 } & 2050 & 297.1 & 148.5 \\
\hline \multirow{3}{*}{ Outlet } & 2025 & 94.1 & 47.0 \\
\cline { 2 - 4 } & 2050 & 328.8 & 164.4 \\
\hline
\end{tabular}

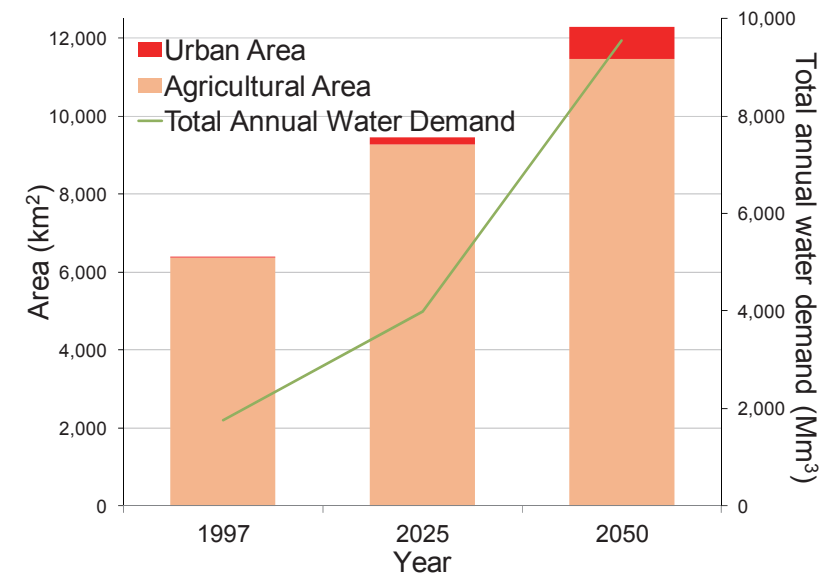

Fig. 5 Total area of agricultural and urban area (Y1 axis) and total annual water demand in 2025 and 2050 (Y2 axis) in the entire Srepok River basin. 
the areas of agriculture and urban in land-cover polygons in 1997 were used to calculate water demand per area for agricultural and urban land types (Table 3). These factors were then multiplied by their respective agricultural and urban areas in each sub-basin to create a new water demand per sub-basin based on future land-cover scenarios. This process is based on the assumption that future water demand per area would remain constant, though water consumption is generally increasing as economy grows. Our total water demand estimation seems valid by comparison with the basic water requirement for human needs calculated by Ty et al. (2009); our estimated total water demand of $3,075.8 \mathrm{Mm}^{3}$ in 2025 in the Vietnamese side of the upper Srepok is less than the $3,699 \mathrm{Mm}^{3}$ in 2020 calculated by Ty et al. In this study, the projected increase of total annual water demand in 2050 from 2025 is more than twice of the increased demand in 2025 from 1997 because urban areas are assumed to increase on a greater scale than agricultural areas with lower water demand per area (Fig. 5). Seasonality was also ac- (a) Ban Don

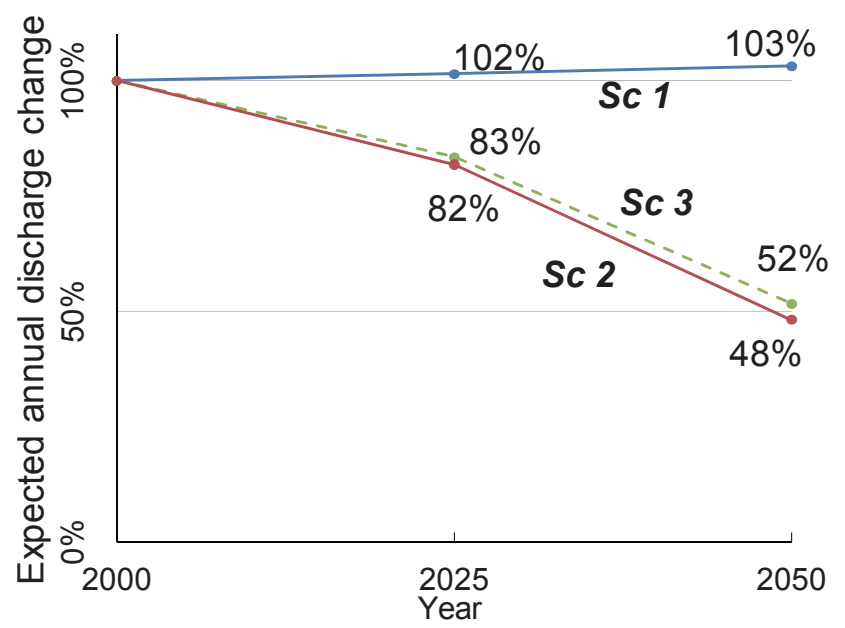

\section{(b) Outlet}

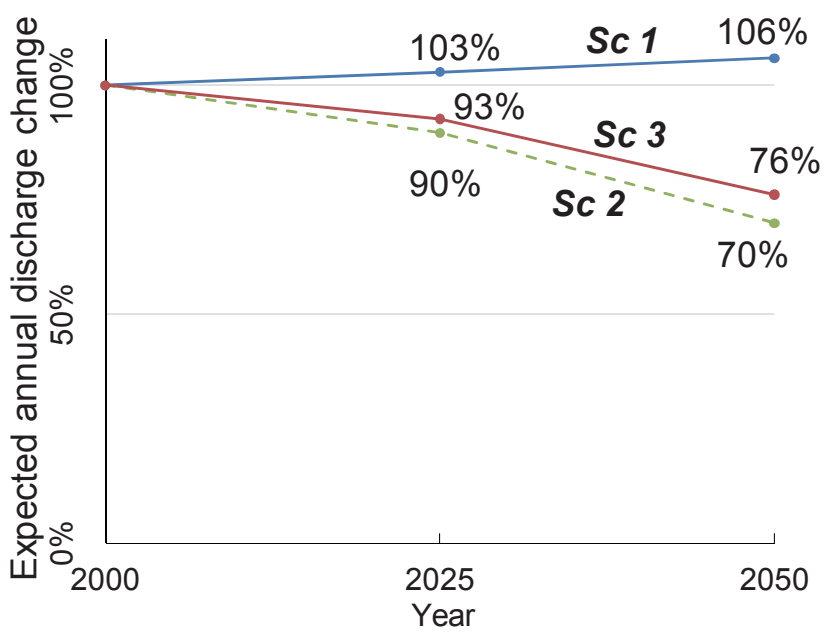

Fig. 6 Predicted annual discharge change for each scenario at (a) Ban Don and (b) the outlet in 2025 and 2050 compared to the level in 2000
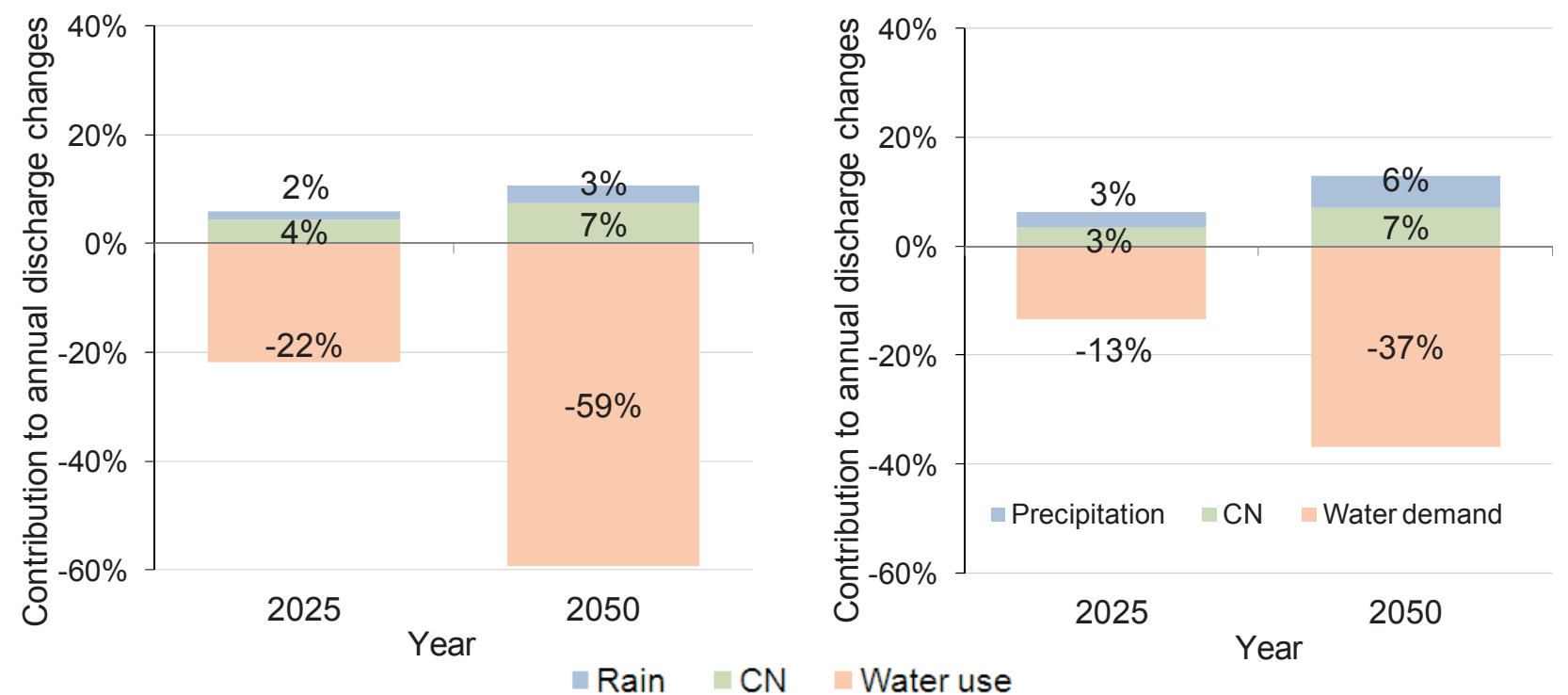

Fig. 7 Contribution of precipitation, $C N$ value, and water demand to the annual discharge change at (a) Ban Don and (b) the outlet in 2025 and 2050 for Sc3 
counted for when calculating annual water demand: Two thirds of water demanded was used for the dry season for greater agricultural usage and one third was used for the wet season (Table 4). This split was based on the seasonal water demand in the upper Srepok River basin; in $2006,591.0 \mathrm{Mm}^{3}$ was used during the wet season and $1,094.6 \mathrm{Mm}^{3}$ was used during the dry season in the area (Ty, 2008).

\section{6 Creating Future Precipitation Scenarios}

For precipitation prediction, some hydrological studies use General Circulation Models (GCMs) available from the IPCC coupled with downscaling techniques (Beyene et al., 2010; Kiem et al., 2008). GCMs are generally more reliable for temperature predictions than for precipitation, wind, humidity or air pressure predictions. Though new methods such as ensemble-based ap-
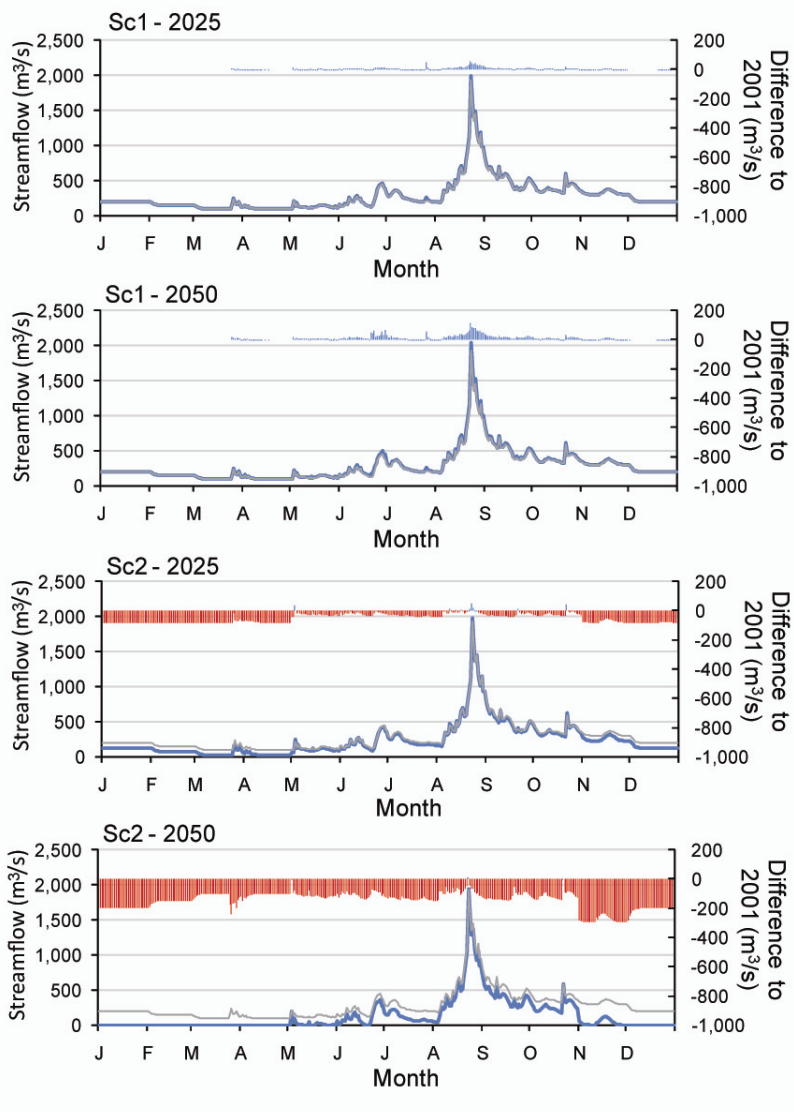

-Increase Decrease - Simulated -2001

Fig. 8 Predicted time-series streamflow (Y1 axis) and difference from 2000 (Y2 axis) at Ban Don in 2025 and 2050 for Sc 1 and Sc2. proaches are developed for evaluating uncertainties and its interpretation has been improved in the IPCC AR4, quantitative projections of precipitation change at the river-basin scale remain uncertain (Kundzewicz et al., 2007). Also, Christofides et al. (2008) demonstrated that these large scale models were unsuitable for predicting regional precipitation change. Therefore, in this local scale study, a simplified approach was taken to develop a future precipitation scenario. Most estimates of global precipitation change using GCMs on the IPCC report vary between no change and $2.5 \%$ increase in 25 years, and no change and 5\% increase in 50 years (Meehl et al., 2007). As an example of climate scenarios using Japan Meteorological Agency atmospheric general circulation model (JMA AGCM) used at IPCC report, Kiem et al. (2008) estimated that annual mean precipitation will increase $6.3 \%$ during 2080-2099 comparing to 1979 1998 in the entire Mekong River basin, and the Srepok River basin is expected to have $10.0 \%$ increase in annual precipitation during 2080-2099. Based on these research results in the study area, $2.5 \%$ and $5.0 \%$ precipitation increase for 2025 and 2050 were assumed as a maximum case of annual precipitation increase and the increase was applied uniformly to the daily 2001 precipitation.

We did not consider any spatial variability of the precipitation change. 'No change' in precipitation was also considered as a baseline case of precipitation change. Temperature change was not considered in the scenario development process since temperature is already indirectly combined into the estimation of precipitation and water demand.

\section{Results}

Streamflow was reviewed at the Ban Don flow station in Vietnam and at the outlet of the Srepok in Cambodia (Fig. 1). Future streamflow was calculated under the three scenarios in Table 5.

Simulations were conducted with the calibrated model based on conditions that reflect each scenario. Simulation results suggest that under the $\mathrm{Sc} 2$ conditions, predicted 
Table 5 Three scenarios developed for evaluating future streamflow

\begin{tabular}{c|l}
\hline Sc1 & $\begin{array}{l}\text { Precipitation change scenario }-2.5 \% \text { and 5\% } \\
\text { uniform precipitation increase in } 2025 \text { and } 2050, \\
\text { respectively, with no change in land-cover and } \\
\text { water demand from the } 2000 \text { levels. }\end{array}$ \\
\hline Sc2 & $\begin{array}{l}\text { Land-cover change scenario - This scenario } \\
\text { reflects predicted } 2025 \text { and } 2050 \text { land-cover and } \\
\text { water demand, while no change was applied in } \\
\text { precipitation: daily precipitation in 2001 was } \\
\text { used for this scenario simulation. This scenario } \\
\text { assumes the lowest end of the expected precipi- } \\
\text { tation change over the next 50 years and helps } \\
\text { us differentiate the impact of land-cover change } \\
\text { from the precipitation change on flow rate. }\end{array}$ \\
\hline Sc3 & $\begin{array}{l}\text { The combination of Sc1 and Sc2 - This sce- } \\
\text { nario reflects both the defined land-cover and } \\
\text { precipitation changes. }\end{array}$ \\
\hline
\end{tabular}

annual discharge decreases by $18 \%$ in 2025 and by $52 \%$ in 2050 compared to the 2000 level at Ban Don; at the basin outlet, predicted annual discharge decreases by $10 \%$ in 2025 and by 30\% in 2050 (Fig. 6). However, under Sc1 conditions, annual discharge increases with the assumed precipitation increase by $2 \%$ and $3 \%$ in Ban Don and by 3\% and 6\% in the basin outlet in 2025 and 2050, respectively. The combined scenario Sc3 result was very similar to that of $\mathrm{Sc} 2$ because the water demand increase would overwhelm the precipitation increase.

Predicted annual discharge decrease at Ban Don would be more severe than that at the basin outlet because most development is expected upstream of Ban Don, such as Buon Ma Thout, Krong Pak, and Krong Ana in Vietnam, which have population densities in 2004 of 852 persons/ $\mathrm{km}^{2}, 349$ persons $/ \mathrm{km}^{2}$, and 306 persons $/ \mathrm{km}^{2}$, respectively.

Figure 7 illustrates the contribution of precipitation, $C N$ value, and water demand change to the predicted annual discharge change at Ban Don and basin outlet in 2025 and 2050 under Sc3. Water demand is the only factor that reduces streamflow since urbanization, which increases $C N$ value, is considered to increase peak flow due to quicker runoff. At Ban Don, predicted water demand contributes to decrease streamflow by $22 \%$ and $59 \%$ in 2025 and 2050 from the level of 2000 , and at the basin outlet, predicted water demand decreases streamflow by $13 \%$ and $37 \%$ in 2025 and 2050. Land-cover change increases annual discharge by $3-4 \%$ and $7 \%$ in 2025 and 2050 at Ban Don and the basin outlet.

Time-series results at Ban Don under two scenarios in 2025 and 2050 are shown in Fig. 8. Simulated streamflow patterns for 2025 and 2050 are similar to that for 2001 because the distribution of future precipitation is assumed to be the same as the 2001 precipitation pattern. During the summer rainy season, streamflow would increase due to quicker and larger runoff created by the slightly increased precipitation. However, flow rate would decrease for most of the year and the decrease would be severe for the dry months from November to March. In the simulation, minimum streamflow was set to zero if the water use exceeded the available water supply. Water demand exceeded streamflow for 5 months in the dry season in 2050 under Sc3.

\section{Discussion and Conclusions}

This study demonstrates the magnitude of potential impact of changes in both precipitation, human activity and their combination on local streamflow, and its effect on the extent of seasonal variation. These results indicate that water demand increase, due to population growth and land development, has a greater impact on streamflow change than precipitation in the next 50 years. This suggests that adaptation planning should be considered to maintain steady water supply especially in the dry season. Adaptation requires policy adjustments in land development, although this may be difficult since economic incentives are important in the region and there is great momentum to expand agricultural land in the area. Additional water infrastructure, such as large dams, for both hydropower and water storage, and smaller reservoirs should be considered in the region to avoid the predicted dry season water shortages.

Some limitations in this research are addressed. The same distribution of daily 2001 precipitation was used to create future daily precipitation. This is not a realis- 
tic scenario although the simplification helps us better understand flow changes for each scenario. In order to capture the effect of local climate variability, longer time span of data need to be analyzed. Spatial and temporal data were very limited in Cambodia. Several assumptions had to be made such as population increase and human water demand based on the Vietnam data.

Though several assumptions and simplifications were applied, this study proposes a simple methodology to integrate available data and findings and conventional methodologies through a common GIS computing environment. The methodology to evaluate impacts of precipitation, land-cover and corresponding $\mathrm{CN}$ value and water demand on streamflow rate in next 50 years is simple and practical. Regarding the prediction of streamflow decrease, it is important to understand quantitatively whether it is due to runoff reduction modelled by changes in curve number, or human water demand increase. The predicted results can be used as a basis for setting priorities for local policy considerations, research for climate adaptation, and urban and regional planning, in the Srepok River basin and beyond.

\section{Acknowledgement}

We would like to thank the editor and reviewers of GISA for valuable suggestion and comments. We are especially grateful to Mr. Tran Van Ty, a former graduate student of the Asian Institute of Technology, for his support of data collection in Vietnam, and also Mr. Pham Tan Ha, Senior Advisor and Project Manager of MRCGTZ Cooperation Program Watershed Management Project, for his valuable suggestions. We appreciate the Mekong River Commissions for their helpful advice and provision of data. We would like to thank Prof. Kimiro Meguro, Institute of Industrial Science, The University of Tokyo for valuable support and suggestions. This study was aided by Research Fellowships of the Japan Society for the Promotion of Science for Young Scientists, and the Harvard University Center for the Environment's Undergraduate Summer Research Assistantships.

\section{References}

Acharya, A.K., Nangia, P. (2004) Population growth and changing land-use pattern in Mumbai metropolitan region of India. Caminhos de Geografia, 11(11), 168-185. Almeida, C.M., Gleriani, J.M., Castejon, E.F., SoaresFilho, B.S. (2008) Using neural networks and cellular automata for modelling intra-urban land-use dynamics. International Journal of Geographical Information Science, 22(9), 943-963.

Beyene, T., Lettenmaier, D.P., Kabat, P. (2010) Hydrologic impacts of climate change on the Nile River basin: Implications of the 2007 IPCC climate scenarios. Climatic Change, 100, 433-461.

Boochabun, K., Vongtanaboon, S., Sukrarasmi, A., Tangham, N. (2007) Impact of land-use development on the water balance and flow regime of the Chi River Basin, Thailand. In Sawada, H., Araki, M., Chappell, N.A., LaFrankie, J.V., Simizu, A. eds. Forest Environments in the Mekong River Basin, Tokyo: Springer, 24-35.

CarlBro Intelligent Solutions (2005) Sre Pok River Basin Profile, Report No.T-203-1.

Chow, V.T., Maidment, D.R., Mays, L.W. (1988) Applied Hydrology. New York: McGraw-Hil.

Christofides, A., Koutsoyiannis, D., Efstratiadis, A., Mammassis, N. (2008) On the credibility of climate predictions. Hydrological Sciences, 53(4), 671-684.

CIESIN (2008) Gridded Population of the World. Center for International Earth Science Information Network, Columbia University.

$<$ sedac.ciesin.columbia.edu/plue/>.

Downs, P.W., Priestnall, G. (1999) System design for catchment-scale approaches to studying river channel adjustments using a GIS. International Journal of Geographical Information Science, 13(3), 247-266.

Haddeland, I., Lettenmaier, D.P., Skaugen, T. (2006) Effects of irrigation on the water and energy balances of the Colorado and Mekong River basins. Journal of Hydrology, 324(1-4), 210-223.

Haruyama, S., Hoa, L. (2010) Recent flood of the Mekong River Delta and their impacts for agriculture. In 
Herath, S., Wang. Y., Liang, L. eds. Meeting Climate Change Challenges in Transboundary Basins: Role of Sciences. CECAR Series No.4, Tokyo: United Nations University, 203-212.

Ishidaira, H., Ishikawa, Y., Funada, S., Takeuchi, K. (2008) Estimating the evolution of vegetation cover and its hydrological impact in the Mekong River Basin in the 21st century. Hydrological Processes, 22(9), 1395-1405. Jarvie, H.P., Oguchi, T., Neal, C. (2002) Exploring the linkages between river water chemistry and watershed characteristics using GIS-based catchment and locality analysis. Regional Environmental Change, 3, 36-50.

Kawasaki, A., Yoshida, S., Sadohara, S. (2007) Outline of water resources GIS application, Arc hydro, and case studies in the United States. Theory and Applications of GIS, 15(1), 29-37.

Kiem, A.S., Ishidaira, H., Hapuarachchi, H.P., Zhou, M.C., Hirabayashi, Y., Takeuchi, K. (2008) Future hydroclimatology of the Mekong River basin simulated using the high-resolution Japan Meteorological Agency (JMA) AGCM. Hydrological Processes, 22, 1382-1394.

Kundzewicz, Z.W., Mata, L.J., Arnell, N.W., Doll, P., Kabat, P., Jimenez, B., Miller, K.A., Oki, T., Sen, Z., Shiklomanov, I.A. (2007) Freshwater resources and their management. Climate Change 2007: Impacts, Adaptation and Vulnerability. Contribution of Working Group II to the Fourth Assessment Report of the Intergovernmental Panel on Climate Change, M. L. Parry, Canziani, O.F., Palutikof, J.P., Van Der Linden, P.J., Hanson, C.E., ed., Cambridge University Press, Cambridge, UK.

Longley, P.A., Goodchild, M.F., Maguire, D.J., Rhind, D.V. (2005) Geographic Information Systems and Sciences, 2nd ed. Chichester: John Wiley \& Sons Ltd.

Maidment, D.R. (2002) Arc Hydro: GIS for Water Resources. Redlands: ESRI Press.

Maidment, D.R. (2008) Bringing Water Data Together. Journal of Water Resources Planning \& Management, 134(2), 95-96.

McCuen, R.H. (1982) A Guide to Hydrologic Analysis Using SCS Methods. Englewood Cliffs: Prentice Hall,
Inc.

Meehl, G.A., Stocker, T.F., Collins, W.D., Friedlingstein, P., Gaye, A., Gregory, J.M., Kitoh, A., Knutti, R., Murphy, J.M., Noda, A., Raper, S.C.B., Watterson, I. G., Weaver, A.J., Zhao, Z.C. (2007) Global Climate Projections. Climate Change 2007: The Physical Science Basis. Contribution of Working Group I to the Fourth Assessment Report of the Intergovernmental Panel on Climate Change, S. Solomon, D. Qin, Manning, M., Z. Chen, M. Marquis, K.B. Averyt, M. Tignor, H.L. Miller, eds., Cambridge University Press, Cambridge, UK and New York, USA.

Mekong River Commission (2007) Diagnostic study of water quality in the Lower Mekong Basin: MRC Technical Paper 15. Mekong River Commission. <http://www. mrcmekong.org/download/free_download/Technical_ paper15.pdf $>$.

Milly, P.C.D., Dunne, K.A., Vecchia, A.V. (2005) Global pattern of trends in streamflow and water availability in a changing climate. Nature, 438(7066), 347-350.

Nagasaki, H., Watanabe, K., Ohgai, A., Divigalpitiya, P., Kondo, A. (2006) Development of a land use planning support tool in the developing countries. Theory and Applications of GIS, 14(2), 85-96.

Oki, T., Kanae, S. (2006) Global hydrological cycles and world water resources. Science, 313(5790), 1068-1072.

Patino-Gomez, C., McKinney, D.C., Maidment, D.R. (2007) Sharing water resources data in the binational Rio Grande/Bravo Basin. Journal of Water Resources Planning \& Management, 133(5), 416-426.

Pielke, R. (2005) Main Conclusions. Climate Science: Roger Pielke Sr. Research Group News. <climatesci.org/ main-conclusions/>.

Rajin, K., Shibasaki, R. (2000) Land use/cover changes and water resources: Experiences form AGENT-LUC model. Proceedings of the AP FRIEND Workshop on Mekong Basin Studies, 1-16.

Rogers, P. (2008) Coping with global warming and climate change. Journal of Water Resources Planning and Management, 134(3), 203-204. 
Soil Conservation Service (1986) Urban Hydrology for Small Watersheds, Technical Release 55 (TR-55), CPESC, Inc. <www.cpesc.org/reference/tr55.pdf>.

Steinitz, C., Faris, R., Flaxman, M., Karish, K., Mellinger, A.D., Canfield, T., Sucre, L. (2005) A delicate balance: Conservation and development scenarios for Panama's Coiba National Park. Environment, 47(5), 2439.

SWECO Groner (2006) Electricity of Vietnam: Environmental Impact Assessment on the Cambodian Side of the Srepok River due to Hydropower Development in Vietnam: Final Report. Norway: SWECO Groner.

Takeuchi, K. (2008) Studies on the Mekong River Basin: Modelling of hydrology and water resources. Hydrological Process, 22, 1243-1245.

Ty, T.V. (2008) GIS Application on Water Infrastructure Inventory and Accessibility of Water Resources in the Upper Srepok Basin, Central Highlands, Vietnam. Master's dissertation, School of Engineering and Technology, Asian Institute of Technology.

Ty, T.V., Babel, M.S., Sunada, K., Oishi, S., Kawasaki, A. (2009) Utilization of a GIS-based water infrastructure inventory for water resources assessment at local level: A case study in mountainous area of Vietnam. Hydrological Research Letters, 3, 27-31.

US Army Corps of Engineers (2009) HEC-HMS. US Army Corps of Engineers, Hydrologic Engineering Cen- ter. <www.hec.usace.army.mil/software/>.

Vorosmarty, C.J., Green, P., Salisbury, J., Lammers, R.B. (2000) Global water resources: Vulnerability from climate change acid population growth. Science, 289(5477), 284-288.

Wassmann, R., Hien, Nx., Hoanh, Ct., Tuong, Tp. (2004) Sea level rise affecting the Vietnamese Mekong delta: Water elevation in the flood season and implications for rice production. Climate Change, 66(1-2), 89-107.

Weesakul, U. (2010) Influence of deforestation on climate change: Future water availability in Chi and Mun river basins. In Herath, S., Wang, Y., Liang, L. eds. Meeting Climate Change Challenges in Transboundary Basins: Role of Sciences. CECAR Series No.4, Tokyo: United Nations University, 213-224.

Whiteaker, T.L., Maidment, D.R., Goodall, J.L., Takamatsu, M. (2006) Integrating Arc Hydro features with a schematic network. Transactions in GIS, 10(2), 219-237. World Wildlife Fund (2008) First Contact in the Greater Mekong. World Wildlife Fund. <assets.panda.org/ downloads/first_contact_final_report.pdf>.

Xia, L., Xiaoping, L. (2008) Embedding sustainable development strategies in agent-based models for use as a planning tool. International Journal of Geographical Information Science, 22, 21-45.

(2009年 11 月 12 日原稿受理, 2010 年 7 月 6 日採用 決定， 2010 年 9 月 30 日デジタルライブラリ掲載） 